To cite this article: Isdhiega Arya Subiyantara, Bagus Haryono and Argyo Demartoto (2022). THE IMPLANTATION OF EDUCATIVE VALUES INTO CHILDREN THROUGH MANGKUBUMEN DOLANAN BOCAH, International Journal of Education and Social Science Research (IJESSR) 5 (1): 34-41

\title{
THE IMPLANTATION OF EDUCATIVE VALUES INTO CHILDREN THROUGH MANGKUBUMEN DOLANAN BOCAH
}

\author{
Isdhiega Arya Subiyantara', Bagus Haryono ${ }^{2}$ and Argyo Demartoto ${ }^{3}$ \\ ${ }^{1}$ Magister Sociology, FISIP Universitas Sebelas Maret \\ ${ }^{2}$ Sociology, FISIP Universitas Sebelas Maret \\ ${ }^{3}$ Sociology, FISIP Universitas Sebelas Maret
}

DOI: http://dx.doi.org/10.37500/IJESSR.2022.5104

\begin{abstract}
The objective of research is to analyze educative values contained in the activity of Mangkubumen Dolanan Bocah (Mangku Dolah). Mangku Dolah is a program launched by Kelurahan Mangkubumen Government as a media used to provide educative values and to inculcate leadership character into children through traditional games. The method employed in this research was descriptive qualitative one with case study analysis technique. Data sources were obtained through primary and secondary data. Primary data derived from direct interview and field observation. Secondary data was obtained from such documents as Monographic Data of Kelurahan, journals, and books. Informant selection was carried out using purposive sampling method. To improve data validity, method triangulation technique was used. The result of discussion shows that (1) traditional game can be used as a media for children to interact with each other through playing together, (2) traditional game can be utilized as a medium of socialization for the children, particularly to inculcate educative values. AGIL (Adaptation, Goal Attainment, Integration, and Latency) scheme was used as the analysis unit to see the Mangku Dolah process. Through a well-planned system, educative values contained in traditional game can be reactivated and introduced to modern children.
\end{abstract}

KEYWORDS: Educative Value, Traditional Game, Mangku Dolah

\section{INTRODUCTION}

Value is literally defined as something considered good and bad by people. Value can be the basis of consideration for each individual to determine attitude and to make decision. Value includes cognitive, affective, and psychomotor competencies to act. Cognitive competency contributes to "determining perspective" used by an individual to appraise others (e.g. empathy, sympathy, admiration, and negative feelings like angry, pain, shy, and guilty) (Santrock, 2002).

The values can be found in people's daily life, including traditional games. In Indonesia, particularly in Javanese people, there are many traditional games very popular among children: gobak sodor, engklek, cublak-cublak suweng, engrang, congklak and so on. 
Educative values can be found anywhere and internalized into community, school, and family environments, among others, through traditional games. The essence of educative value implantation is a process of creating, growing, developing, and maturing child's personality to be wise and responsible person. Meanwhile, the educative values contained in traditional games, according to Dharmamulyo (1999), includes happiness, feeling of being friends, democratic values, leadership value, feeling of being responsible, togetherness value, obedience value, practicing thinking skill, sportsmanship, and practicing environmental concern. Ariani (1997) states that there are seven values in traditional games: democratic, educational, personality, bravery, health, unity, and moral values.

Children (particularly 3-12 years old) love games; thus, games are considered to facilitate the implantation of values into children, because they are free and joyful in nature. Children in kindergarten and elementary school are inseparable from the word "playing". Playing, according to Aristotle, Plato and Frobel (in Mayke S. Tedjasaputra, 2007), has practical value, meaning that playing is used as a medium to improve certain skill and competency in children. Traditional games are considered to be able to inculcate a number of positive values into children.

As time goes by exactly when globalization and modernization eras grow so rapidly, traditional games are instead more marginalized and unknown to the people. Technology advance plays an important role in creating behavior and interaction in the society, including children. Through interaction occurring in cyberspace, the playing world of children has shifted now from playing, interacting and communicating directly with peers into playing, interacting, and communicating with peers digitally.

Traditional game prioritizes cooperation, communication, and competition. The game is sometimes competitive in nature, just like modern game in gadget like playstation, Nintendo, X-Box, computer, and handphone, but educative values contained in traditional game are of course very different from modern technology-based game.

Traditional game is no longer popular today, because in modern era, traditional game begins to be forgotten, and replaced with gadget. During COVID-19 pandemic, Indonesian children did online learning, so that their intensity of meeting their fellows is low at both home and school environment. Otherwise, children have high intensity of holding gadget. In its development gadget is not functioned as learning aid for school but also utilized by children as a playing media. Eventually, the popularity of traditional game is replaced with modern game culture, particularly in Indonesian big cities like Surakarta.

The creation of Mangku Dolah is originally aimed at minimizing the negative effect of modernization. The most clear effect of modernization can be seen from the more sophisticated tools used in human daily life, having serious implication to the dominant individualism and rare social interaction pattern. It is inseparable from the one-way role of modern game (watching the screen), rather than verbal and non-verbal interaction with fellows. The game played at home is more individual in nature. Those 
games do not develop the child's social skill. Children can be bright and smart but their social intelligence is inadequate (Seriati and Nur, 2012).

Through Mangku Dolah, children are reintroduced with traditional game. Many values can be taken from traditional games, one of which is engklek. In Central Java community, particularly in Surakarta Residency, engklek is a game played by drawing some box on the floor, then the player throw gaco made of roof-tile or plasterboard fragment. Gaco is thrown, and then the player jumps to the place where the gaco is put. This play involves some aspects: agility, adroitness, and skill in playing gaco. There is also gobak sodor game prioritizing compactness in team game. This game of course involved physical activity, thereby stimulating the motor system of children playing in addition to making their body healthy.

This research focuses on two points: firstly, how traditional game can be used as a medium for children to interact with their fellows, and secondly how traditional game can be utilized as a means of socialization to the children, particularly in implanting educative values into them.

\section{MATERIALS AND METHODS}

This study was qualitative research, taking place in Kelurahan Mangkubumen, Banjarsari Sub District, Surakarta City, Central Java Province, Indonesia. The method used in this research was descriptive qualitative one, with case study analysis. Data source was obtained through primary and secondary data. Primary data derived from direct interview and field observation. Secondary data was obtained from such documents Monographic data of Kelurahan, journals, and books. Informant selection was carried out using purposive sampling method. The informants selected in this research were: 1) Head of Mangkubumen Village (Lurah Mangkubumen), 2) Kelurahan officers, and 3) parents and children affiliated with Mangku Dolah. To improve data validity, method triangulation technique was used.

\section{DISCUSSION}

Traditional game is the manifestation of local wisdom that has been born since hundreds or even thousands years ago. The process of human culture in ancient age had known game as a recreational process with many functions. Despite its very old age, traditional game in fact plays a very humane educating role to the learning process of an individual, particularly child. It is because traditional game can naturally stimulate various aspects of child development: motor, cognitive, emotional, language, social, spiritual, and values (Misbach, 2006).

Generally, traditional game has original local characteristic, in accordance with the local cultural tradition. Therefore, in its implementation, the elements of folk game and kid game are often included into traditional game. Traditional kid game contains educative values not visible directly, but hidden in some symbols and the values are multidimensional, involving feeling of togetherness, honesty, discipline, modesty, mutual cooperation (gotong royong), and other personality aspects (Arikunto in Halim, 2014). The implantation of values emphasizes that education is not only related to the 
acquisition of knowledge but also grows various attitudes, values, messages, and high ideals to children. It means that education is no longer oriented to the children's success in comprehending the learning material at school, but how the children's positive character can be established in the learning process (Solihati, 2017).

Various traditional games inherited from Javanese ancestors are still played until today. One of traditional games contains values is gobag sodor. The values contained in gobag sodor are, among others, honesty, sportsmanship, cooperation, strategic setting, and leadership (Siagawati, 2007). Value can be conceived as general concepts about something considered good, proper, reasonable, and feasible, the existence of which is idealized, wanted, understood, and implemented in daily life, and becomes the common life goal in the community group (Nugrahastuti, 2019).

Traditional game is generally played independently based on the children's initiative. However, it is in contrast to the context of current research, in which the author found something unique in the implementation of traditional game. Generally, children do not know the function and the objective of playing game. They do so because they think it is joyful. In addition to have cultural value to be preserved, adults try to utilize traditional game as a means of educating or implanting educative values to children.

Mangku Dolah is a movement established by Kelurahan Mangkubumen government aiming to preserve, to insert educative values, and to reintroduce traditional games. This movement was initiated by Mr. Beni Supartono as the Head of Mangkubumen Village. The target of Mangku Dolah activity is the children aged 5-12 years in Kelurahan Mangkubumen. This traditional game is played routinely ever Friday afternoon in many places, particularly in pendopo kelurahan or Sasana Krida yard.

On Friday afternoon, children assemble in the yard of Sasana Krida to play together. Despite coming from the same kelurahan (village), sometimes they do not know each other. The process of socializing with each other will then create warm interaction and aims to create sportive and joyful game. So the first educative value to be taken is the process of socialization. From the socialization process, then trust grows and children begin to know each other and make friends. Furthermore, educative values are implanted in the playing process. In this research, the author focuses on gobak sodor game. This game indirectly teaches the children about socialization, communication, group solidarity, team work, and leadership value.

\section{RESULT}

Traditional game is very popular before the entry of technology into Indonesia. Children, particularly at kindergarten and elementary school levels, play using simple instruments. These varying traditional games have some functions, particularly as entertainment or recreation media. Another function is as learning media. Competition game featuring physical skill, for example, functions to develop motor nervous of children who play. Tactical competition game functions to develop thinking ability. In 
addition, traditional games also functions as learning, one of which is the implantation of educative values into children including socialization, communication, group solidarity, team work, and leadership value.

Children prefer the game in inculcating values as it is free and joyful. Traditional game like gobag sodor can be used to implant educative values into children. Ariani (1997) says that the creation of gobak sodor game was originally inspired with the training for the Court's soldiers who did battle simulation in alun-alun (town square). The term gobak sodor is defined as a type of game done on a plot of spacious land with rectangular lines in some boxes, played freely by rotating, consisting of two groups: a group serving as player or in Javanese called mentas and another one serving as the guard or in Javanese called "dadi, each of which consists of 4-7 members adjusted with the number of boxes (Marsono, 1999). Meanwhile, according to Ariani (1997), the words gobak sodor derived from foreign language, go back to door. The change of idiom into Javanese is due to the spelling adaptation.

The gobak sodor game functions as self-entertainment, to grow creativity, and to grow personality. In playing gobak sodor, children are expected to learn some good attitudes like helping each other, tolerance, and appreciating each others. The values contained in gobak sodor traditional game are taken from the children's statement as expressed in the definition aforementioned. The values are, among others, happiness, honesty, sportsmanship, life struggle, cooperation, compactness, social skill, health, agility, strategic setting, and leadership.

The transfer of value in gobak sodor game occurs through understanding directly the playing experience. Children will have honesty because they should try to be honest in playing. Also, children can obtain value through the habituation of rules existing in the game. For example, children accustomed to be sportive will have sportsmanship value. In addition, children will acquire value by imitating it from older people. Children will do strategic setting or lead through imitating it from the older children who lead and organize the gobak sodor game, so that the younger children will have strategic setting and leadership values. In addition, children will capture values more easily through parents or older people's explanation.

Edgar Dale with his The Cone of Experience theory states that direct experience with traditional game gets primary and biggest place in the acquisition of knowledge. Meanwhile, learning through something abstract seems to be on the top of cone. James L. Mursell states that a successful learning is to learn by doing, tracking, searching, and then finding something searched for. Learning is experience, exploration and discovery (Rasyad: 2006). And all of them abide in traditional game.

Mangku Dolah as an attempt of preserving traditional game, of course, needs a social system as a functional requirement in order to run duly. Summarizing Talcott Parsons's (1951) statement, functional requirement can be explained as a social system that should adapt to environment and transformation demand in any people condition or action (adaptation). Furthermore, people's action is 
directed to achieve the goal (goal attainment). Then, another requirement is that in the interaction between citizens should at least contain solidarity level, to make structure and social system function (integration). There is also pattern maintenance to keep the system run appropriately (latency). In latency, system should complement, maintain, and improve both individual motivation and cultural patterns creating and supporting the social motivation. To maintain the consistency of traditional game, as the executor of program, the Kelurahan Mangkubumen government through Mangku Dolah should meet AGIL requirement. Based on the result of interview with informants, the author can develop the AGIL scheme, as follows:

\begin{tabular}{|c|c|c|}
\hline No & $\begin{array}{l}\text { AGIL } \\
\text { Scheme }\end{array}$ & Mangku Dolah \\
\hline 1 & Adaptation & $\begin{array}{l}\text { First Group: } \\
\text { Routine meeting in Sasana Krida to practice dance is the } \\
\text { group playing traditional game routinely (primary group) } \\
\text { Second group: } \\
\text { Attempting to adapt to peers when playing together in the } \\
\text { yard of kelurahan/sasana krida (secondary group). }\end{array}$ \\
\hline 2 & $\begin{array}{l}\text { Goal } \\
\text { Attainment }\end{array}$ & $\begin{array}{l}\text { 1. Introducing traditional game to Mangkubumen children } \\
\text { 2. Minimizing the effect of modernization } \\
\text { 3. Introducing surrounding environment/social interaction to } \\
\text { children } \\
\text { 4. Introducing educative values to children } \\
\text { 5. Creating polite, cultured, and sensible next generations }\end{array}$ \\
\hline 3 & Integration & $\begin{array}{l}\text { 1. Playing together } \\
\text { 2. Routine meeting } \\
\text { 3. Maintaining compactness } \\
\text { 4. Wish to keep establishing social relation and interaction } \\
\text { beyond the game held by Kelurahan } \\
\text { 5. Shared hobby of game }\end{array}$ \\
\hline 4 & Latency & $\begin{array}{l}\text { 1. Kelurahan Government facilitates the children's hobby in } \\
\text { game }\end{array}$ \\
\hline
\end{tabular}




\begin{tabular}{|l|l|l|}
\hline & $\begin{array}{l}\text { 2. Creating safe and comfortable public space for children's } \\
\text { play ground }\end{array}$ \\
\hline
\end{tabular}

Source: Primary Data, processed in July 2021

Kelurahan Mangkubumen Government, through Mangku Dolah program wants to introduce and to popularize traditional game to children. The objective is to inculcate educative values and to habituate children to socialize and interact with friends in their surrounding environment. Talcott Parsons's AGIL scheme can be used to analyze the process from the beginning to how Mangku Dolah maintains the consistency pattern in preserving traditional game in Kelurahan Mangkubumen environment.

\section{CONCLUSION}

Educative values can be implanted in early childhood (preschool to elementary school age) joyfully without patronizing, using traditional game media. The educative values that can be learnt from gobak sodor game are courage, activeness in taking initiative, sociability, togetherness, honesty, rule obedience, strategy setting, skill, agility, friendship, leadership, and self-confidence. This Mangku Dolah program, in addition to being used as a means to make the children familiar with each other in Kelurahan Mangkubumen environment, can also be a medium for children to interact with peers. The process of socialization and interaction between peers through traditional game is expected to create a harmonious community, the members of which can cooperate, respect each other, and are not individualist (the effect of technology modernization). Therefore, Adaptation, Goal Attainment, Integration and Latency processes play important roles as the unit of analysis for Mangku Dolah to implant educative values consistently into children through traditional game. Finally, the long-term objective of Mangku Dolah to create generations with positive value and character can be achieved, and traditional game can be maintained and preserved as the part of Javanese culture.

\section{REFERENCES}

1. Ariani, dkk. 1992. Permainan Takyat Daerah Istimewa Yogyakarta. Yogyakarta: Departemen Pendidikan dan Kebudayaan Daerah Istimewa Yogyakarta.

2. Ariani, dkk. 1997. Pembinaan Nilai Budaya Melalui Permainan Rakyat Daerah Istimewa Yogyakarta. Jakarta: Depdiknas.

3. Dharmamulyo, S. 1992. Transformasi Nilai Budaya Melalui Permainan Anak DIY. Yogyakarta: Proyek P2NB.

4. Halim, F. M. 2014. Interior Museum Permainan Anak-Anak Tradisional Jawa di Surabaya. Jurnal Intra, 2 (2), hlm. 1.

5. Santrock J. W. 2002. Life-Span Development Perkembangan Masa Hidup; Jilid I. Edisi kelima. Jakarta: Erlangga.

6. Mayke, S. 1995. Bermain, Mainan dan Permainan. Jakarta: Dirjen Pendidikan Tinggi.

7. Hayati, N., Seriati, N. N., \& Nurhayati, L. (2012). Kegiatan bermain berbasis art craft bagi anak usia dini untuk mempromosikan kecintaan pada lingkungan. Jurnal Kependidikan, 42(2), 152161. 


\section{International Journal of Education and Social Science Research}

ISSN 2581-5148

Vol. 5, Issue.1, Jan-Feb 2022, p no. 34-41

8. Marsono, dkk. 1999. Berbagai Permainan Tradisional Masyarakat Jawa. Yogyakarta: Lembaga Studi Jawa Yogyakarta.

9. Misbach, I. H. 2006. Peran permainan tradisional yang bermuatan edukatif dalam menyumbang pembentukan karakter dan identitas bangsa. Laporan Penelitian.

10. Mumtazinur. 2019. Ilmu Sosial dan Budaya Dasar. Banda Aceh: Lembaga Kajian Konstitusi Indonesia (LKKI) Fakultas Syariah dan Hukum, Universitas Islam Negeri (UIN) Ar-Raniry. ISBN 978-602-50172-4-7.

11. Nugrahastuti, Eka, dkk. 2019. Nilai-Nilai Karakter Pada Permainan Tradisional, Prosiding Seminar Nasional Inovasi Pendidikan Inovasi Pembelajaran Berbasis Karakter dalam Menghadapi Masyarakat Ekonomi ASEAN.

12. Parsons, T. 1951. Teori Struktural Fungsional. Jakarta: Aksara Persada Pers

13. Rasyad, Aminuddin. 2006. Teori Belajar dan Pembelajaran, Jakarta. Uhamka Press.

14. Siagawati, M, Wiwin, D. P, Purwati. 2007. Mengungkap Nilai-Nilai Yang Terkandung Dalam Permainan Tradisional Gobag Sodor. Indigenous, Jurnal Ilmiah Berkala Psikologi, 9 (1). hlm. 3 , $7,11$.

15. Solihati, N. 2017. Aspek pendidikan karakter dalam puisi hamka. LITERA, 16(1), 51-63. 